\title{
Oskar Minkowski (1858-1931). An outstanding master of diabetes research
}

\author{
Victor Jörgens*
}

Executive Director, EASD/EFSD, Düsseldorf, Germany

\begin{abstract}
Oskar Minkowski, a physician of many talents, was an outstanding clinical scientist, a brilliant experimental investigator and a prolific medical writer. His name is connected with highly important clinical studies and experimental probes, all of which significantly contributed to our understanding of the pathogenesis of diabetes mellitus after removal of the pancreas (experimental pancreatectomy).
\end{abstract}

Key words: Diabetic coma, Experimental pancreatectomy, Diabetes mellitus, Josef von Mering, Oskar Minkowski

Oskar Minkowski was born on 13 January 1858 in Alexoten, Russia (today Alexotas, Lithuania), a town situated directly across the river from Kaunas, Lithuania. His parents were Levin and Rachel Minkowski. In 1872 the family was forced to sell off everything hurriedly and leave Alexoten because of the policy of anti-Semitic persecution adopted by the tsar's government. The family emigrated to Königsberg in Prussia, which a year earlier had been incorporated into the German Empire. In Königsberg, Oskar's father turned to a new trade, the export of white linen rags. The children, feeling distressed about this change in profession, queried their mother who explained that their father's new occupation was one

\footnotetext{
Address correspondence and requests for reprints to:

Dr Med. Victor Jörgens, Executive Director, EASD/EFSD,

Rheindorfer Weg 3, D - 40591 - Düsseldorf, Germany,

Phone: +49-211-7584690, Fax: +49-211-75846929,

E-mail: viktorjoergens@easd.org

Received 03-01-06, Revised 10-05-06, Accepted 10-07-06
}

of the noblest since the paper of the fine books that they loved could be made only from such rags. The eldest son, Max, subsequently took over the family business in Königsberg, became prosperous as a grain middle-man and served as the French consul. Oskar's younger brother, Hermann, became a world famous professor of mathematics, was a teacher of Einstein and published the book Space and Time. If he had not died so early due to a perforated appendix in 1909, he certainly would have become as famous as Einstein.

Oskar Minkowski attended the famous Altstädter Gymnasium in Königsberg, and subsequently studied medicine at the universities of Freiburg and Königsberg. At the University of Königsberg, where Immanuel Kant had been a teacher of Philosophy and where the ophthalmoscope was invented by

\footnotetext{
* Presented at the Symposium on the History of Diabetes held in Delphi, September 7-9, 2005
} 
the physicist Helmholtz, he worked with Professor Bernhard Naunyn. His thesis was accepted on 17 December 1881. Bernhard Naunyn was nominated for the chair of internal medicine at the University of Strasburg to succeed Adolf Kussmaul; Minkowski followed him in 1888. He became professor in Strasburg where he worked until 1904. In Cologne he was head of the department of medicine of the Catholic City Hospital, Augusta Krankenhaus (the building was destroyed in World War II) and moved to the chair of internal medicine in Greifswald in 1905. From 1909 to 1926 he served as head of the department of internal medicine at the university of Breslau (today Wroclaw in Poland).

Oskar Minkowski has entered the annals of the history of medicine for several great discoveries. One of these is the first description of beta-hydroxybutyrate in diabetic coma. But his major discovery was indubitably his experiments in Strasburg in 1898 revealing the existence of pancreatic diabetes following pancreatectomy in dogs. He was nominated six times for the Nobel Prize. The first publication on diabetes following pancreatectomy in dogs was co-signed by Josef von Mering (1849-1908) and Minkowski. The surgery required for the experiments was performed by Minkowski with von Mehring only acting as assistant. Nevertheless, it was von Mehring who provided Minkowski with the incentive to perform the experiment since, according to Claude Bernard, the young researcher had considered pancreatectomy to be impossible. The experiments were undertaken to evaluate the absorption of fat following pancreatectomy and were not aimed at all at diabetes research. It was to Minkowski's merit that he associated the polyurea which occurred in the dog to the diabetic state and thus tested the urine for glucose and ketones. Following this first discovery, he undertook numerous studies which he summarised admirably. ${ }^{1-3}$

It was only once Minkowski was established in the chair of internal medicine at Breslau (Wroclaw) that he was finally able to form and guide a leading group of clinical researchers. Besides his prominent position as a leading diabetologist in Europe, he became one of the most famous German internists, evidenced by the fact that he chaired the German Association of Internal Medicine and was consulted for the care of numerous famous personages, including Vladimir Ilyich Lenin.

After retirement, Minkowski settled in Wiesbaden. He had planned to move to Berlin to an apartment newly decorated by his wife, when he was hospitalised because of pneumonia. He died in a hospital owned by one of his students in Fórstenberg, Mecklenburg on 18 June 1931. His remains, together with those of his renowned brother, Hermann Minkowski, are buried in the cemetery on Heerstrasse, Berlin and preserved by the city of Berlin as an historical monument.

The Minkowski family was one of the most outstanding families in European science. They stand for innovative, breakthrough ideas followed by welldesigned experiments and precise observation of unexpected results and their interpretation. Since 1966 the European Association for the Study of Diabetes has awarded the Minkowski Prize for outstanding contributions to the advancement of knowledge in the field of diabetes mellitus. The Prize is conferred on a scientist of under forty years of age: Oskar Minkowski was 31 when, thanks to his momentous discovery, he orientated diabetes research towards the true target, namely the endocrine function of the pancreas.

\section{ACKNOWLEDGEMENTS}

Lorenz Minkowski, Walnut Creek, California, the grandson of Oscar Minkowski, who provided much valuable information on Oskar Minkowski.

\section{REFERENCES}

1. Houssay BA 1952 The discovery of pancreatic diabetes. The role of Oskar Minkowski.

2. von Mering J, Minkowski O, 1890 Diabetes mellitus nach Pankreasextirpation. Archiv fór experimentelle Pathologie und Pharmakologie 26: 371-378.

3. Minkowski O, 1893 Untersuchungen óber den Diabetes mellitus nach Exstirpation des Pankreas. Arch f Ex Path U Pharmakol 31: 85-189. 